\title{
Reduced Sensitivity in Monilinia fructicola Field Isolates from South Carolina and Georgia to Respiration Inhibitor Fungicides
}

\author{
A. Amiri, Department of Entomology, Soils, and Plant Sciences, Clemson University, Clemson, SC 29634; \\ P. M. Brannen, Department of Plant Pathology, University of Georgia, Athens 30602; and G. Schnabel, Department \\ of Entomology, Soils, and Plant Sciences, Clemson University
}

\begin{abstract}
Amiri, A., Brannen, P. M., and Schnabel, G. 2010. Reduced sensitivity in Monilinia fructicola field isolates from South Carolina and Georgia to respiration inhibitor fungicides. Plant Dis. 94:737-743.

Quinone outside inhibitor (QoI) and succinate dehydrogenase inhibitor (SdhI) fungicides are respiration inhibitors (RIs) used for preharvest control of brown rot of stone fruit. Both chemical classes are site-specific and, thus, prone to resistance development. Between 2006 and 2008, 157 isolates of Monilinia fructicola collected from multiple peach and nectarine orchards with or without RI spray history in South Carolina and Georgia were characterized based upon conidial germination and mycelial growth inhibition for their sensitivity to QoI fungicides azoxystrobin and pyraclostrobin, SdhI fungicide boscalid, and a mixture of pyraclostrobin + boscalid. There was no significant difference $(P=0.05)$ between $\mathrm{EC}_{50}$ values for inhibition of conidial germination versus mycelial growth. The mean $\mathrm{EC}_{50}$ values based upon mycelial growth tests for 25 isolates from an orchard without RI-spray history were $0.15,0.06,2.23$, and $0.09 \mu \mathrm{g} / \mathrm{ml}$ for azoxystrobin, pyraclostrobin, boscalid, and pyraclostrobin + boscalid, respectively. The respective mean $\mathrm{EC}_{50}$ values for 76 isolates from RI-sprayed orchards in South Carolina were 0.9, 0.1, 10.7 , and $0.13 \mu \mathrm{g} / \mathrm{ml}$ and for 56 isolates from RI-sprayed orchards in Georgia were 1.2, 0.1, 8.91 , and $0.17 \mu \mathrm{g} / \mathrm{ml}$. Overall, mean $\mathrm{EC}_{50}$ values of populations from RI-sprayed orchards increased three-, two-, five-, and twofold between 2006 and 2008 for azoxystrobin, pyraclostrobin, boscalid, and pyraclostrobin + boscalid, respectively. A subset of $10 \mathrm{M}$. fructicola isolates representing low and high $\mathrm{EC}_{50}$ values for azoxystrobin, boscalid, and boscalid + pyraclostrobin was selected for a detached fruit assay to determine disease incidence and severity following protective treatments of formulated RI fungicides at label rates. Brown rot incidence was greater than $50 \%$ when fruit were inoculated with isolates having $\mathrm{EC}_{50}$ values of 2,4 , and $0.6 \mu \mathrm{g} / \mathrm{ml}$ for azoxystrobin, boscalid, and pyraclostrobin + boscalid, respectively. Pyraclostrobin failed to control any of the isolates tested in detached fruit assays. Based on minimum inhibitory concentration and brown rot incidence data, we recommend using 3 and $0.75 \mu \mathrm{g} / \mathrm{ml}$ as discriminatory doses to distinguish between sensitive isolates and those with reduced sensitivity to azoxystrobin and pyraclostrobin + boscalid, respectively. Results from our in vitro and in vivo assays indicate a shift toward reduced sensitivity in $M$. fructicola from the southeastern United States. No cross-resistance was observed between the QoI and the SdhI fungicides, which implies that rotation or tank mixtures of these two chemical classes can be used as a resistance management strategy.
\end{abstract}

Quinone outside inhibitor (QoI) and succinate dehydrogenase inhibitor (SdhI) fungicides are respiration inhibitor (RI) fungicides that play an essential role in the management of preharvest brown rot disease caused by Monilinia fructicola in peach production areas in the southeastern United States. In light of existing benzimidazole (BZI) and demethylation inhibitor (DMI) fungicide resistance in the region $(2,25,35,36)$, producers have relied heavily on QoI and SdhI fungicides since their introduction in 2002. Some producers use

Corresponding author: G. Schnabel

E-mail: schnabe@clemson.edu

Accepted for publication 15 February 2010.

doi:10.1094/PDIS-94-6-0737

(C) 2010 The American Phytopathological Society them exclusively while others use them in rotation with DMIs for preharvest brown rot control.

QoI fungicides such as azoxystrobin and pyraclostrobin were originally developed from natural fungicidal derivatives such as strobilurin A and oudemansin (4,6). They specifically bind to the ubihydroquinone reduction site $\left(\mathrm{Q}_{0}\right.$-site $)$ and inhibit the electron transport chain in the mitochondrial respiratory chain of the complex $b c l$, also known as the complex III $(6,7)$. SdhI fungicides such as boscalid, carboxin, and flutolanil interfere with the enzyme succinate dehydrogenase reductase (SQR), a component of complex II in the mitochondrial electron transport chain $(15,32)$. The inhibition of mitochondrial respiration resulting from the QoI or SdhI action leads to a disruption of the energy cycle (6). Pyraclostrobin is currently formulated as a mixture with boscalid for blossom blight and preharvest brown rot management in the United States.

RI fungicides are prone to resistance development due to their site-specific mode of action. Field resistance to QoI fungicides has been reported in many pathogens affecting fruit, including Alternaria mali (16), Venturia inaequalis (31), Podosphaera fusca, Pseudoperonospora cubensis (11), Botrytis cinerea, (12) and Mycosphaerella fijiensis (27). Fewer cases of SdhI fungicide resistance have been reported. Examples include A. alternata (5) and Podosphaera xanthii (17). Reduced sensitivity to RI fungicides has not been reported in Monilinia spp. despite frequent use since 2002. Resistance to QoI fungicides has been linked to three amino acid substitutions in the cytochrome $b$ gene in many plant pathogens: a change from glycine to alanine at position 143 (G143A) and from phenylalanine to leucine at position 129 (F129L), and a substitution of glycine by arginine at position 137 (G137R) $(13,21,28)$. The G143A mutation can lead to complete control failure $(13,14,27,28)$, whereas the F129L mutation has been shown to convey partial resistance $(13,21,33)$. However, field resistance to the QoIs is not always linked to a particular point mutation in the cytochrome $b$ gene (9).

The objectives of this study were to determine (i) the baseline sensitivity to QoI and SdhI fungicides in M. fructicola isolates collected from an orchard that had never been sprayed with RI fungicides in South Carolina; (ii) the in vitro sensitivity to azoxystrobin, pyraclostrobin, boscalid, and boscalid + pyraclostrobin of $M$. fructicola isolates collected from commercial orchards with a history of RI exposure; and (iii) the relationship between reduced sensitivity in vitro and the ability to cause brown rot disease on RI fungicide-treated, detached peach fruit.

\section{MATERIALS AND METHODS}

Fungicides. Commercial formulations of azoxystrobin (Abound 2.08F, 22.4\% active ingredient [a.i.]; Syngenta Crop Protection, Greensboro, NC), boscalid (Endura, $70 \%$ a.i.; BASF, Research Triangle Park, NC), pyraclostrobin (Cabrio EC, $20 \%$ a.i.; BASF), and a mixture of boscalid and pyraclostrobin (Pristine, $12.8 \%$ pyraclostrobin and $25.2 \%$ boscalid; BASF) were used in this study. For the in vitro 
assays, the fungicides were dissolved in $\mathrm{vol} / \mathrm{vol}$ ) and adjusted to concentrations of $5 \mathrm{mg}$ a.i./ml for azoxystrobin, pyraclostrobin, and boscalid. The stock solution of pyraclostrobin + boscalid consisted of Pristine formulated product at $7 \mu \mathrm{g} / \mathrm{ml}$. For consistency (i.e., listing active ingredient as treatment name), we refer to Pristine as pyraclostrobin + boscalid. Stock solutions were stored at $4{ }^{\circ} \mathrm{C}$ and added to autoclaved medium cooled to $50^{\circ} \mathrm{C}$. For in vivo assays, the formulated products were dissolved in sterile distilled water and applied to peach fruit at rates equivalent to those recommended under field conditions as detailed below.

Collection, isolation, and maintenance of M. fructicola isolates. From 2006 to spores were collected from an abandoned orchard plus 2 experimental and 14 commercial peach orchards representing nearly all major production regions in South Carolina and Georgia (Table 1). Twentyfive isolates were collected from an abandoned orchard never sprayed with RI fungicides (BJ, baseline population) in Spartanburg County, SC. The remaining commercial orchards had been sprayed regularly with RIs since 2002 (Table 1).

Peach fruit with sporulating brown rot lesions were collected from individual trees in selected orchards, so that each fruit was from a different tree. Fruit were placed separately in plastic containers with the sporulating lesion facing up. Lids were closed to avoid spore dispersal and fruit were transported to the laboratory. Singlespore isolates were obtained within $24 \mathrm{~h}$ as described previously (26). Isolates used in all assays were grown on potato dextrose agar (PDA) and stored at $4^{\circ} \mathrm{C}$. In this study, isolates collected from orchards with a history of RI sprays are referred to methanol and sterile distilled water (1:5, 2008, 157 isolates originating from single

as "RI-sprayed" as opposed to "baseline isolates".

Inoculum preparation. Conidia from M. fructicola isolates were produced on canned peach fruit. Cling stone peach halves in pear juice (Great Value brand; Wal-Mart, Bentonville, AR) were placed in sterile Magenta GA-7 culture boxes (Magenta Corp., Chicago) with the pit side facing down. Each peach half was inoculated with three 5-mm plugs from the margin of a 5- to 7-day-old colony of each single isolate growing on PDA and then incubated for 7 days at $22^{\circ} \mathrm{C}$. Distilled water $(10 \mathrm{ml})$ containing $0.05 \%$ Tween 80 was added to each culture box and conidia were detached by scratching the sporulating area with a sterile cotton swab. The resulting spore suspension was filtered through a double layer of cheesecloth and the concentration was determined using a hemacytometer. The final concentration of the suspension was adjusted to $4 \times 10^{5}$ conidia/ml. Conidial suspensions were prepared immediately before an experiment started and kept on ice during experimental procedures.

Sensitivity of conidia and mycelium of M. fructicola to fungicides. Azoxystrobin and pyraclostrobin were added to autoclaved PDA cooled to $50^{\circ} \mathrm{C}$ to produce concentrations of $0,0.001,0.01,0.1,1,10$ $\mu \mathrm{g}$ a.i. $/ \mathrm{ml}$ of medium. Boscalid was added to PDA at final concentrations of $0,0.05$, $0.5,5$, and $50 \mu \mathrm{g}$ a.i./ml. Pyraclostrobin + boscalid were added to PDA in the form of Pristine formulated product to produce concentrations of Pristine fungicide at 0 , $0.001,0.01,0.1,1$, and $10 \mu \mathrm{g} / \mathrm{ml}$ of medium. Salicylhydroxamic acid (SHAM; Acros Organics, Morris Plains, NJ) was dissolved in methanol and distilled water and added to azoxystrobin-, pyraclostrobin-, or pyraclostrobin + boscalidamended PDA at $100 \mu \mathrm{g} / \mathrm{ml}$. Preliminary

Table 1. Origin of Monilinia fructicola isolates used in this studyw

\begin{tabular}{llrlc}
\hline State, county & Orchard & $\boldsymbol{n}^{\mathbf{x}}$ & \multicolumn{1}{c}{ Cultivar } & RI fungicides sprayed since \\
\hline South Carolina & & & & \\
Spartanburg & WH & 11 & Silver Shedfield & 2003 \\
& JC & 8 & O'Henry & 2003 \\
& MB & 7 & Red Gold & 2003 \\
& DM & 8 & N/A & 2003 \\
Anderson & BJ & 25 & N/A & NS \\
Pickens & ZR & 7 & N/A & 2003 \\
Edgefield & MF & 8 & Coronet & 2002 \\
& ST & 7 & Sun Prince & 2003 \\
& FR & 7 & Harvester & 2002 \\
Saluda & CP & 8 & Summer Gold & 2002 \\
Georgia & TS & 6 & Harvester & 2002 \\
Peach & & & & 2002 \\
& BR & 12 & N/A & 2003 \\
Crawford & SL & 13 & Prestige & 2002 \\
Roberta & DS & 11 & Red Globe & 2004 \\
\hline
\end{tabular}

\footnotetext{
${ }^{\mathrm{w}} \mathrm{RI}=$ respiration inhibitor, $\mathrm{N} / \mathrm{A}=$ not applicable, and NS = never sprayed.

${ }^{\mathrm{x}}$ Number of isolates collected from each location.

${ }^{\mathrm{y}}$ Baseline population.

${ }^{\mathrm{z}}$ Experimental orchard.
}

tests showed no effect of SHAM on the inhibitory activity of boscalid on mycelial growth or conidial germination of M. fructicola (data not shown); therefore, SHAM was not added to boscalid-amended PDA.

For conidial sensitivity evaluation, a $100-\mu \mathrm{l}$ aliquot of spore suspension $\left(4 \times 10^{5}\right.$ conidia/ml) of each isolate was spread evenly onto solidified PDA in petri dishes using a sterilized glass rod. Dishes were placed in sterile plastic bags and incubated in dark at $22^{\circ} \mathrm{C}$, and percent germination was determined after 12 to $16 \mathrm{~h}$. To calculate germination frequencies, each petri dish was divided into thirds with a marker and, in total, 100 spores per third were investigated under a microscope. A conidium was considered to be "germinated" when it had produced a germ tube two times longer than its diameter. Two petridish replicates of each fungicide concentration were assessed for each isolate.

To test mycelium sensitivity, mycelial plugs ( $5 \mathrm{~mm}$ in diameter) taken from the advancing margins of 7-day-old colonies of each isolate were transferred to PDA. Each dish was inoculated with three plugs and three petri dishes were inoculated for each isolate-fungicide concentration combination. Dishes were sealed with Parafilm and incubated at $22^{\circ} \mathrm{C}$ in the dark, and radial mycelial growth was measured after $72 \mathrm{~h}$. Colony diameter was measured in two perpendicular directions from the edge of each plug. The mean diameter was used to calculate percent inhibition relative to the unamended PDA control.

Efficacy of RI fungicide applications for brown rot control on peach fruit. Ten isolates possessing different effective concentration of fungicide inhibiting mycelial growth by $50 \%\left(\mathrm{EC}_{50}\right)$ values to QoI and SdhI fungicides were assessed for their ability to cause disease on fungicidetreated fruit. In addition to $\mathrm{EC}_{50}$ values, the minimum inhibitory concentration (MIC) for azoxystrobin, boscalid, and pyraclostrobin + boscalid was determined for isolates used in detached-fruit assays. Isolates were grown on PDA amended with azoxystrobin at $0.5,1,2,3,4,6$, and $8 \mu \mathrm{g} / \mathrm{ml}$; boscalid at $5,10,20,30$, and $40 \mu \mathrm{g} / \mathrm{ml}$; or pyraclostrobin + boscalid at $0.01,0.1$ and 1 $\mu \mathrm{g} / \mathrm{ml}$. The MIC value indicated the lowest concentration of the fungicide at which complete mycelial growth inhibition was observed. Peach fruit (cv. Red Skin) were harvested at commercial maturity at the Clemson University Musser Fruit Research Center, Seneca, SC. Fruit surfaces were cleaned and prepared for inoculation as explained previously (8). Briefly, fruit were stab inoculated at three equidistant points to a depth of $9.5 \mathrm{~mm}$ using a 26G3/8 9.5-mm beveled syringe tip (Becton Dickson \& Co., Rutherford, NJ) and immediately sprayed using a 1-liter plastic sprayer (Consolidated Plastic Company, Inc., Twinsburg, OH). Fruit were sprayed either with sterile water (control) or with 
field rates of Abound 2.08F (1.7 ml/liter), Endura (1.34 g/liter), Cabrio EC (0.9 $\mathrm{g} / \mathrm{liter}$ ), or Pristine (1.08 g/liter) and stored at room temperature for $12 \mathrm{~h}$ before inoculation. A $30-\mu l$ droplet of a $5 \times 10^{4}$ conidia/ml suspension from each isolate was placed on each wound using a micropipette. The fruit were stored in the dark in sealed humidity chambers at room temperature for $72 \mathrm{~h}$ before determining brown rot incidence and severity. Disease incidence (DI) was expressed as the percentage of wounds infected compared with the total number of wounds inoculated. The diameter of each wound was measured and the mean diameter from each treatment was used to determine the disease severity (DS) using the following formula $\mathrm{DS} \%=([$ mean diameter of the control mean diameter of the treatment $] /[$ mean diameter of the control]) $\times 100$. Three replicate peach fruit were used for each isolate-fungicide concentration combination and the experiment was conducted twice following a randomized complete block design.

Data analysis. Data from spore germination and mycelial growth tests were used to calculate percent inhibition relative to the unamended PDA control. Values from germination and growth inhibition were plotted against $\log _{10}$-transformed fungicide concentrations and $\mathrm{EC}_{50}$ values $(\mu \mathrm{g} / \mathrm{ml})$ were determined for each isolate based on parameter estimates from the regression equation. Analyses were conducted to compare $\mathrm{EC}_{50}$ values of isolates based on conidial germination and mycelial growth to each fungicide separately and to compare the isolates from the baseline population with those from the sprayed populations. $\mathrm{EC}_{50}$ values were compared using a two-way multivariate analysis of variance (ANOVA) and protected least significant difference (LSD) for means separation. Variation factors (VFs) for the population were calculated by dividing the highest $\mathrm{EC}_{50}$ value by the lowest $\mathrm{EC}_{50}$ value of isolates within the same population. Crossresistance among fungicides was determined by calculating a Pearson product moment correlation coefficient from the $\mathrm{EC}_{50}$ values of isolates for azoxystrobin, pyraclostrobin, boscalid, and pyraclostrobin + boscalid. Results from the two experimental runs on efficacy of fungicides on detached fruit assays did not differ statistically $(P=0.05)$ following separate ANOVA analyses; therefore, data from the two runs were plotted for final ANOVA analysis. Means were separated using Fisher's protected LSD test. Interaction between pyraclostrobin and boscalid in the Pristine mixture was calculated based on the $\mathrm{EC}_{50}$ values of mycelial growth using the Abbot Formula (1), $C_{\exp }=A+B-$ $(A B / 100)$, in which $C_{\text {exp }}$ is the expected efficacy of the mixture and $A$ and $B$ are the pyraclostrobin and boscalid control levels (based on mycelial growth), respectively.
The ratio, $\mathrm{R}$, between the $\mathrm{C}_{\mathrm{obs}}$ (observed) and $\mathrm{C}_{\exp }$ (expected) efficacies of the mixture was calculated as $\mathrm{R}=\mathrm{C}_{\mathrm{obs}} / \mathrm{C}_{\text {exp }}$. If $\mathrm{R}$ was greater than, equal to, or less than 1 , then interaction between compounds was characterized as synergistic, additive, or antagonistic, respectively. $\mathrm{EC}_{50}$ values of isolates collected in 2006, 2007, and 2008 were compared using an ANOVA and means were separated by the protected LSD test. All statistical tests were used at a significance level of 0.05 and all statistical analyses were performed using SigmaStat software (version 3.00; SPSS Inc., Chicago).

\section{RESULTS}

Sensitivity of $M$. fructicola baseline and RI-sprayed populations to RI fungicides. In the conidial germination assay, the $\mathrm{EC}_{50}$ values ranged from 0.05 to 0.6 $(\mathrm{VF}=12)$ for azoxystrobin, 0.02 to 0.18 $(\mathrm{VF}=9)$ for pyraclostrobin, 0.91 to 3.17 $(\mathrm{VF}=3.5)$ for boscalid, and 0.07 to 0.31 $(\mathrm{VF}=4.4)$ for pyraclostrobin + boscalid (Fig. 1; Table 2). The $\mathrm{EC}_{50}$ values obtained by mycelial growth inhibition ranged from 0.09 to $0.27 \mu \mathrm{g} / \mathrm{ml}$ for azoxystrobin, 0.01 to $0.11 \mu \mathrm{g} / \mathrm{ml}$ for pyraclostrobin, 0.82 to $2.85 \mu \mathrm{g} / \mathrm{ml}$ for boscalid, and 0.05 to 0.18 $\mu \mathrm{g} / \mathrm{ml}$ for pyraclostrobin + boscalid (Fig. 1). Corresponding VFs for mycelial growth were $3.0,11.0,3.5$, and 3.6, respectively (Table 2).

The mean $\mathrm{EC}_{50}$ values of $\mathrm{RI}$-sprayed populations were significantly $(P=0.02)$ higher than the baseline population for all RI fungicides, with the exception of the pyraclostrobin + boscalid mixture (Table 2 ). The variability in $\mathrm{EC}_{50}$ values of the sprayed population was higher (greater VF) compared with the baseline population. The highest $\mathrm{EC}_{50}$ values based upon conidial germination tests were 4.98, $0.72,20.64$, and $1.71 \mu \mathrm{g} / \mathrm{ml}$ for azoxystrobin, pyraclostrobin, boscalid, and pyraclostrobin + boscalid, respectively. There were no significant differences $(P$ $=0.05$ ) between $\mathrm{EC}_{50}$ values of conidial germination and mycelial growth tests; however, $\mathrm{EC}_{50}$ values obtained in mycelial growth assays were always numerically lower, except for boscalid (Table 2). The highest resistance factors (RFs) were observed for azoxystrobin followed by boscalid, pyraclostrobin, and pyraclostrobin + boscalid, consecutively. Overall, $\mathrm{EC}_{50}$ and $\mathrm{RF}$ values observed for South Carolina populations were comparable with those observed for populations from Georgia (Table 2).

Cross-resistance between and among RI fungicides. There was a significant positive correlation between the $\mathrm{EC}_{50}$ values for QoI fungicides azoxystrobin and pyraclostrobin $(r=0.57 ; P=0.01$; Table $3)$. The correlation coefficient between $\mathrm{EC}_{50}$ values for pyraclostrobin + boscalid and boscalid alone was lower but still significant ( $r=0.47 ; P=0.02)$. Correlation coefficients between boscalid and azoxystrobin $(r=0.05)$ and between boscalid and pyraclostrobin $(r=0.08)$ were not significant (Table 3 ).

Sensitivity shift of M. fructicola populations. Although not always statistically significant at the $P=0.05$ level, there was a steady increase over 3 years in $\mathrm{EC}_{50}$ values and, thus, a reduction of sensitivity over time for each fungicide tested (Fig. 2). For boscalid, the mean $\mathrm{EC}_{50}$ values increased significantly with each year of isolation. Mean $\mathrm{EC}_{50}$ values increased three-, two-, five-, and twofold between 2006 and 2008 for azoxystrobin, pyraclostrobin, boscalid, and pyraclostrobin + boscalid, respectively. Isolates collected in 2007 and 2008 but not 2006 had significantly $(P=0.03)$ higher mean $\mathrm{EC}_{50}$ values to boscalid compared with the baseline population (Fig. 2A). With one exception, all populations collected between 2006 and 2008 were less sensitive to azoxystrobin, pyraclostrobin, and pyraclostrobin + boscalid compared with the baseline population (Fig. 2B).

Efficacy of fungicide applications for brown rot control on peach fruit. There was a strong correlation between DI on peach fruit and in vitro sensitivity $\left(\mathrm{EC}_{50}\right.$ value) for azoxystrobin $(P=0.005)$, boscalid $(P=0.01)$, and pyraclostrobin + boscalid $(P=0.01)$. Isolates with DI values $\leq 20 \%$ were categorized as "sensitive" (S) and isolates with DI values $>20 \%$ were categorized as "reduced-sensitive" (RS) (Table 4). Isolates in the $\mathrm{S}$ category had $\mathrm{EC}_{50}$ values up to $0.5,2.0$, and $0.2 \mu \mathrm{g} / \mathrm{ml}$ and isolates in the RS category had $\mathrm{EC}_{50}$ values up to $4.1,14.2$, and $0.6 \mu \mathrm{g} / \mathrm{ml}$ for azoxystrobin, boscalid, and pyraclostrobin + boscalid, respectively (Table 4). Brown rot incidence exceeded $50 \%$ when fruit were inoculated with isolates exhibiting $\mathrm{EC}_{50}$ values of 2,4 , and $0.6 \mu \mathrm{g} / \mathrm{ml}$ for azoxystrobin, boscalid, and pyraclostrobin + boscalid, respectively (Table 4 ). When Cabrio EC (pyraclostrobin) was applied to detached fruit at the label rate, none of the isolates were controlled (data not shown). DS correlated with the $\mathrm{EC}_{50}$ values for the QoI fungicides, in that the higher the $\mathrm{EC}_{50}$, the higher were the DS values on the fruit; however, some fluctuations were observed for boscalid (Table 4).

The MIC values for azoxystrobin $\mathrm{S}$ and RS isolates ranged from 0.5 to 2.0 and 4 to $8 \mu \mathrm{g} / \mathrm{ml}$, respectively (Table 4 ). The MIC value for boscalid $\mathrm{S}$ isolates was $5 \mu \mathrm{g} / \mathrm{ml}$ but values ranged from 10 to $50 \mu \mathrm{g} / \mathrm{ml}$ for boscalid RS isolates. The MIC value was $0.1 \mu \mathrm{g} / \mathrm{ml}$ for pyraclostrobin + boscalid $\mathrm{S}$ isolates and $1 \mu \mathrm{g} / \mathrm{ml}$ for RS isolates, with two exceptions. Isolates GA.Bmpc5 and SC.Egpc6 were considered $\mathrm{S}$ isolates by our definition based on the $\mathrm{EC}_{50}$ and DI values, although their MIC value was 1.0 $\mu \mathrm{g} / \mathrm{ml}$.

The ratio $\mathrm{R}$ between the observed $\left(\mathrm{C}_{\text {obs }}\right)$ and expected $\left(\mathrm{C}_{\text {exp }}\right)$ efficacies of 
the mixture pyraclostrobin + boscalid (Pristine) was between 1 and 1.3 for the 10 isolates tested on detached fruit assays, suggesting an additive effect between the two compounds in the mixture (data not shown).

\section{DISCUSSION}

RI fungicides are strong inhibitors of conidial germination and sporulation $(6,20,24)$ and have been reported to be effective against other stages of fungal growth $(20,30)$. Therefore, sensitivity of
M. fructicola isolates to different RI fungicides was determined using conidial germination and mycelial growth inhibition tests. Both QoI fungicides (i.e., azoxystrobin and pyraclostrobin) had comparable activity on conidial germination and

Conidial germination

Mycelial growth
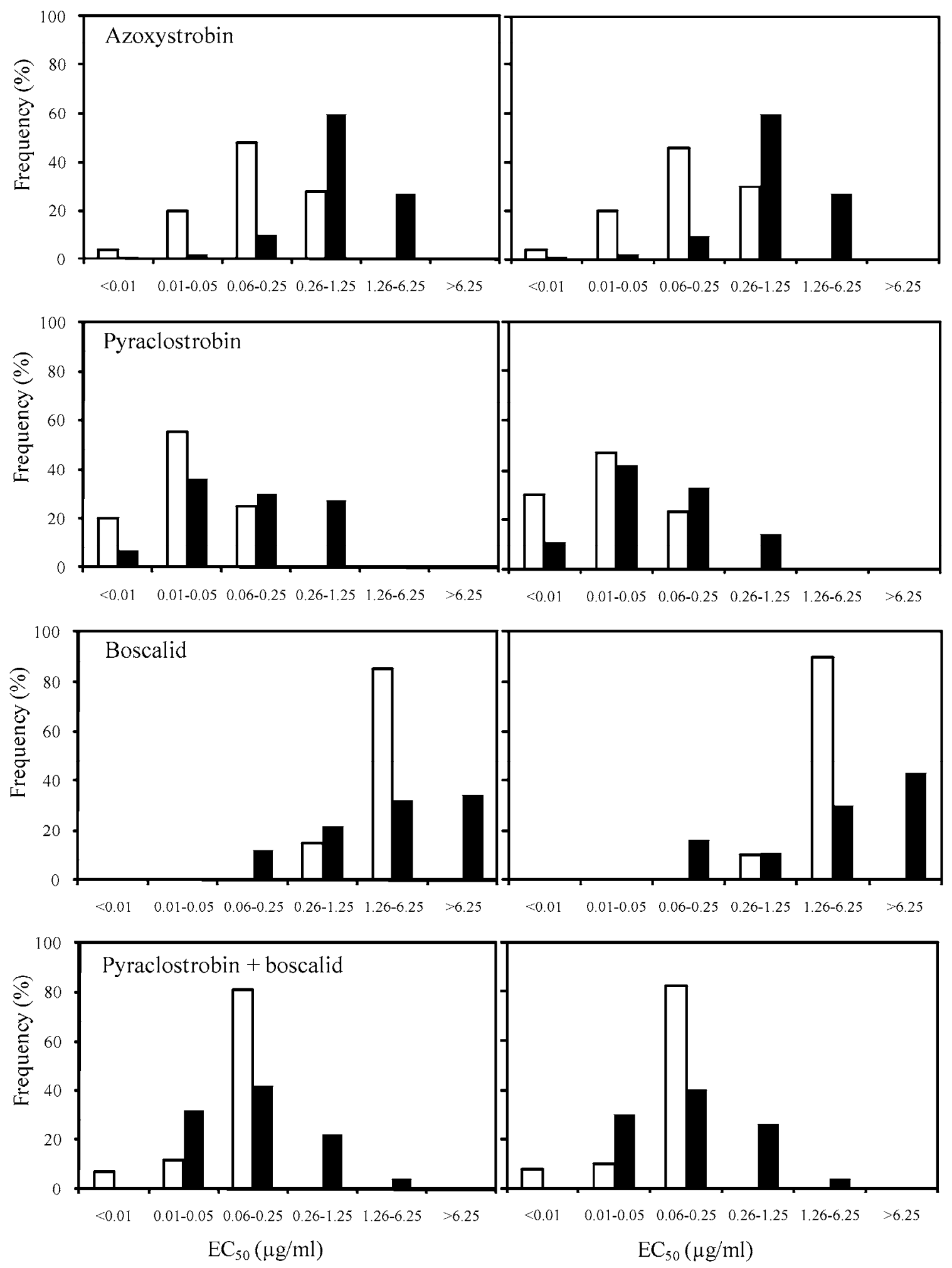

Fig. 1. Sensitivity distribution of Monilinia fructicola isolates from a baseline population (open bars) and respiration inhibitor (RI)-sprayed populations (filled bars) to RI fungicides based upon conidial germination and mycelial growth. Isolates from the baseline population $(n=25)$ were collected from an abandoned orchard in Spartanburg County, SC. RI-sprayed populations $(n=132)$ were collected from multiple commercial orchards in South Carolina and Georgia with a history of RI fungicides use. $\mathrm{EC}_{50}=$ effective concentration of fungicide inhibiting mycelial growth by $50 \%$. 
mycelial growth of $M$. fructicola isolates. Boscalid, however, was less inhibitory to mycelial growth than conidial germination of $M$. fructicola. This is consistent with previous reports showing stronger effects of boscalid against spore germination compared with mycelial growth in $\mathrm{A}$. alternata and B. cinerea $(19,37)$.

To our knowledge, this is the first time pyraclostrobin and boscalid sensitivity data are reported for $M$. fructicola. Sensitivity data have been published for other Monilinia spp., however. The MIC for pyraclostrobin ranged from 0.039 to $0.625 \mu \mathrm{g} / \mathrm{ml}$ for $M$. fructigena and 0.01 to $2.5 \mu \mathrm{g} / \mathrm{ml}$ for M. laxa baseline populations from Europe (29). We did not determine the MIC values for pyraclostrobin; however, our MIC values for azoxystrobin, a QoI fungicide, were in a similar range (i.e., between 0.5 and $2 \mu \mathrm{g} / \mathrm{ml}$ ) for $M$. fructicola baseline isolates. MIC values for boscalid in baseline isolates from South Carolina and Georgia were $5 \mu \mathrm{g} / \mathrm{ml}$, which is higher than reported for M. fructigena (0.039 to $2.5 \mu \mathrm{g} / \mathrm{ml}$ ) and $M$. laxa isolates (0.01 to 2.5 $\mu \mathrm{g} / \mathrm{ml}$ ) (29). Interestingly, the sensitivity of our baseline population to the pyraclostrobin + boscalid mixture was not different compared with pyraclostrobin alone but was significantly lower compared with boscalid. However, this is contrary to what we observed on detached fruit, where boscalid was more active than pyraclostrobin against brown rot. The $\mathrm{EC}_{50}$ values for azoxystrobin in baseline isolates ranged from 0.09 to $0.27 \mu \mathrm{g} / \mathrm{ml}$, which is comparable with $\mathrm{EC}_{50}$ values (0.002 to $1.35 \mu \mathrm{g} / \mathrm{ml}$ ) previously reported for six $M$. fructicola isolates from South Carolina (26).

Our results revealed higher sensitivity to pyraclostrobin compared with azoxystrobin in both baseline and RI-sprayed $M$. fructicola populations. This is consistent with findings from previous studies on several citrus pathogens and Phytophthora cactorum $(18,22)$. Also, differential shifts in sensitivity to azoxystrobin compared with trifloxystrobin have been reported previously in A. solani (21) and to pyraclostrobin compared with trifloxystrobin in Colletotrichum cereale (34). The sensitivity of $M$. fructicola isolates to azoxystrobin and pyraclostrobin was positively correlated, indicating cross-resistance. No cross-resistance was found between the two QoI fungicides and boscalid. This is in agreement with previous reports in other fungal pathogens $(5,21,37)$ and corroborates the existence of different sites and mechanisms of action of these two groups of fungicides.

The significantly higher $\mathrm{EC}_{50}$ values observed for the RI-sprayed populations compared with the baseline population suggest that a shift in $M$. fructicola sensitivity to these fungicides has occurred in the Southeast. This is particularly true for boscalid and azoxystrobin and, to a lesser degree, for the pyraclostrobin + boscalid mixture. It is likely that the frequent application of RI fungicides between 2003 and 2008 has led to the selection of less sensitive populations. Despite the geographical distance (about $320 \mathrm{~km}$ ) between the main peach-growing areas of South Carolina and Georgia, similar RFs were observed for isolates from the two regions. It is probable that South Carolina and Georgia populations shifted independently toward reduced sensitivity to RI fungicides; fungicide selection pressure was likely similar in both states because preharvest brown rot control recommendations have been coordinated through a regional spray program.

Detached fruit assays confirmed a direct correlation between $\mathrm{EC}_{50}$ values and disease development. Regardless of the RI fungicide, isolates with higher $\mathrm{EC}_{50}$ values caused higher DI than isolates with lower $\mathrm{EC}_{50}$ values. Azoxystrobin formulated as Abound 2.08F failed (DI $>10 \%$ ) to control isolates with $\mathrm{EC}_{50}$ values $\geq 0.52 \mu \mathrm{g} / \mathrm{ml}$. The same was true for boscalid formulated as Endura with isolates of $\mathrm{EC}_{50}$ values $>2$ $\mu \mathrm{g} / \mathrm{ml}$ and for pyraclostrobin + boscalid formulated as Pristine with isolates of $\mathrm{EC}_{50}$ values $\geq 0.1 \mu \mathrm{g} / \mathrm{ml}$. Although pyraclostrobin formulated as Cabrio EC showed strong activity in vitro, it did not control brown rot in detached fruit assays regardless of the $\mathrm{EC}_{50}$ value of the isolate. This is consistent with a previous report indicating weak efficacy of pyraclostrobin formulated as BAS 500 for pre- and postharvest brown rot control (23). Cabrio EC, or any other formulation of pyraclostrobin alone, is not registered for brown rot control in stone fruit. The level of interaction between pyraclostrobin and boscalid in the Pristine formulation predicted by the Abbot formula (1) was always between 1 and 1.3 for all 10 isolates tested on detached fruit, suggesting an additive rather than a syner-

Table 3. Correlation coefficients between azoxystrobin, boscalid, pyraclostrobin, and pyraclostrobin + boscalid in Monilinia fructicola field isolates ${ }^{\mathrm{z}}$

\begin{tabular}{lccccc}
\hline & \multicolumn{2}{c}{ Pyraclostrobin } & & \multicolumn{2}{c}{ Boscalid } \\
\cline { 2 - 3 } \cline { 5 - 6 } Fungicide & $\boldsymbol{r}$ & $\boldsymbol{P}$ & & $\boldsymbol{r}$ & $\boldsymbol{P}$ \\
\hline Azoxystrobin & 0.57 & 0.01 & & 0.05 & 0.61 \\
Pyraclostrobin & $\ldots$ & $\ldots$ & & 0.08 & 0.43 \\
Boscalid & 0.08 & 0.43 & & $\ldots$ & $\ldots$ \\
Pyraclostrobin + boscalid & 0.24 & 0.02 & & 0.47 & 0.02 \\
\hline
\end{tabular}

z Pearson correlation coefficient $r$ was calculated from the $50 \%$ effective concentration values of 127 isolates collected from respiration inhibitor-sprayed orchards.

Table 2. Comparison of in vitro sensitivity of Monilinia fructicola isolates from baseline $(n=25)$ and respiration inhibitor (RI)-spayed populations from South Carolina (SC) and Georgia (GA) to RI fungicides ${ }^{\mathrm{y}}$

\begin{tabular}{|c|c|c|c|c|c|c|c|c|}
\hline \multirow[b]{2}{*}{ Population $^{z}$} & \multicolumn{2}{|c|}{ Azoxystrobin } & \multicolumn{2}{|c|}{ Pyraclostrobin } & \multicolumn{2}{|c|}{ Boscalid } & \multicolumn{2}{|c|}{ Pyraclostrobin + boscalid } \\
\hline & Conidia & Mycelium & Conidia & Mycelium & Conidia & Mycelium & Conidia & Mycelium \\
\hline \multicolumn{9}{|l|}{ Baseline } \\
\hline $\begin{array}{l}\text { Mean } \mathrm{EC}_{50} \\
\mathrm{VF}\end{array}$ & $0.15 \pm 0.06 \mathrm{a}$ & $0.07 \pm 0.05 \mathrm{a}$ & $0.06 \pm 0.03 \mathrm{a}$ & $0.04 \pm 0.02 \mathrm{a}$ & $1.97 \pm 0.77 \mathrm{a}$ & $2.23 \pm 0.76 \mathrm{a}$ & $0.09 \pm 0.03 \mathrm{a}$ & $0.09 \pm 0.04 \mathrm{a}$ \\
\hline \multicolumn{9}{|l|}{ RI-sprayed } \\
\hline $\mathrm{SC}(n=76)$ & & & & & & & & \\
\hline Mean $\mathrm{EC}_{50}$ & $1.0 \pm 0.6 \mathrm{~b}$ & $0.9 \pm 0.5 \mathrm{~b}$ & $0.12 \pm 0.08 \mathrm{~b}$ & $0.10 \pm 0.07 \mathrm{~b}$ & $6.4 \pm 3.1 \mathrm{~b}$ & $10.7 \pm 4.7 \mathrm{~b}$ & $0.16 \pm 0.06 \mathrm{a}$ & $0.13 \pm 0.07 \mathrm{a}$ \\
\hline VF & 370 & 108 & 9 & 13 & 202 & 103 & 69 & 80 \\
\hline $\mathrm{RF}$ & 6.6 & 12.9 & 2.0 & 2.5 & 2.9 & 5.4 & 1.7 & 1.4 \\
\hline \multicolumn{9}{|l|}{$\mathrm{GA}(n=56)$} \\
\hline Mean $\mathrm{EC}_{50}$ & $1.4 \pm 0.8 \mathrm{~b}$ & $1.2 \pm 0.6 \mathrm{~b}$ & $0.12 \pm 0.04 b$ & $0.10 \pm 0.06 b$ & $4.63 \pm 2.9 \mathrm{~b}$ & $8.91 \pm 4.8 \mathrm{~b}$ & $0.30 \pm 0.10 \mathrm{~b}$ & $0.17 \pm 0.08 \mathrm{a}$ \\
\hline VF & 83 & 88 & 24 & 82 & 297 & 136 & 134 & 170 \\
\hline $\mathrm{RF}$ & 9.3 & 17.1 & 2.0 & 2.5 & 2.1 & 4.5 & 3.3 & 1.9 \\
\hline
\end{tabular}

y Azoxystrobin, pyraclostrobin, boscalid, and pyraclostrobin + boscalid were applied as Abound, Cabrio, Endura, and Pristine formulated products, respectively.

${ }^{\mathrm{z}}$ Mean effective concentration of fungicide inhibiting mycelial growth by $50 \%\left(\mathrm{EC}_{50}\right)$ value $(\mu \mathrm{g} / \mathrm{ml}) \pm$ standard deviation. Values within each fungicide column followed with same letters are not significantly different based on the least significant difference test $(P=0.05)$. $\mathrm{VF}=$ variation factor calculated by dividing the highest $\mathrm{EC}_{50}$ value by the lowest $\mathrm{EC}_{50}$ value within the same population. $\mathrm{RF}=$ resistance factor calculated by dividing the mean $\mathrm{EC}_{50}$ value of the RI-sprayed population by the mean $\mathrm{EC}_{50}$ value of the baseline population. 

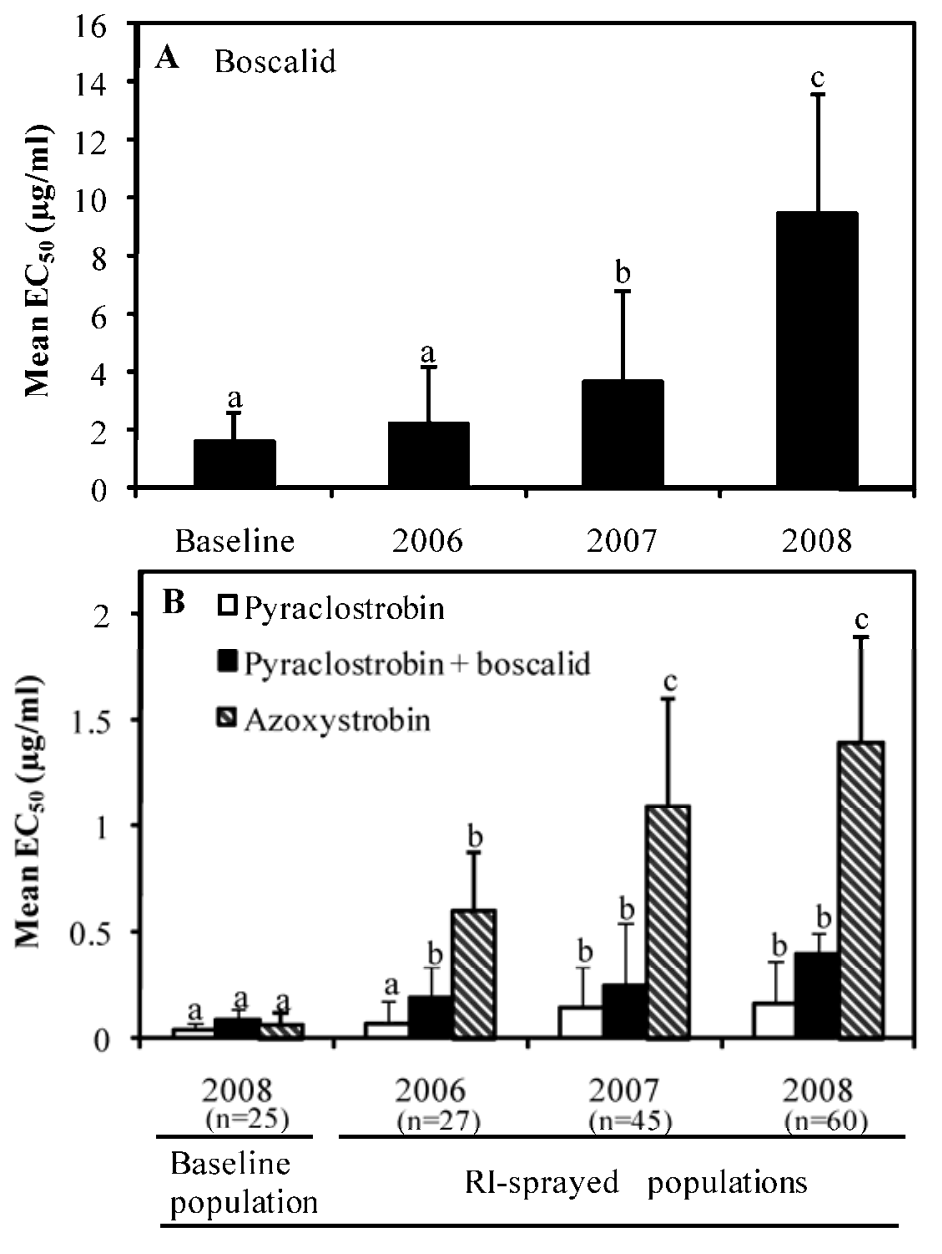

Year of isolation

Fig. 2. Comparison of mean effective concentration of fungicide inhibiting mycelial growth by $50 \%$ $\left(\mathrm{EC}_{50}\right)$ values for Monilinia fructicola baseline and respiration inhibitor (RI)-sprayed populations collected between 2006 and 2008 for A, boscalid and B, pyraclostrobin, pyraclostrobin + boscalid, and azoxystrobin. Vertical bars indicate standard deviations. Columns with distinct letters are significantly different $(P=0.05)$ based upon the least significant difference for each fungicide separately. getic effect of the two compounds, according to a previous classification (10).

Based on the MIC and DI data, we can infer discriminatory doses that will be useful for rapid distinction of $\mathrm{S}$ and $\mathrm{RS}$ isolates. In theory, this dose should inhibit completely $\mathrm{S}$ but not RS isolates. For azoxystrobin, we suggest the discriminatory dose to be $3 \mu \mathrm{g} / \mathrm{ml}$, which is the average value of the highest MIC of $\mathrm{S}$ isolates $(2 \mu \mathrm{g} / \mathrm{ml})$ and the lowest MIC of $\mathrm{R}$ isolates $(4 \mu \mathrm{g} / \mathrm{ml})$. For pyraclostrobin + boscalid, results were less obvious, where borderline $\mathrm{S}$ isolates had the same MIC as RS isolates. Therefore, we suggest the discriminatory dose should be $0.75 \mu \mathrm{g} / \mathrm{ml}$, which is higher than the average value between the highest MIC of the majority of $\mathrm{S}$ isolates $(0.1 \mu \mathrm{g} / \mathrm{ml})$ and the lowest MIC of RS isolates (1 $\mu \mathrm{g} / \mathrm{ml})$.

The shift toward reduced sensitivity to RI fungicides shown in this study has not perceptibly altered the success of these same fungicides in controlling brown rot in the field. Several reasons may have contributed to the continued success in controlling preharvest brown rot disease despite emerging resistance problems. First, particularly dry weather conditions observed during fruit-ripening stages between 2006 and 2008 were not conducive to large brown rot epidemics. Second, region-wide resistance monitoring (2) has enabled growers to identify and react accordingly to existing and emerging resistance problems. Third, the overwhelming majority of Southeastern growers used the

Table 4. Efficacy of respiration inhibitor fungicides for brown rot disease control in detached fruit assays ${ }^{y}$

\begin{tabular}{|c|c|c|c|c|c|c|c|c|c|c|}
\hline \multirow[b]{2}{*}{ Treatment $^{\mathrm{z}}$} & \multicolumn{10}{|c|}{ Monilinia fructicola isolate } \\
\hline & SC.Dap3 & SC.mfp7 & SC.Dm7 & GA.SL1 & SC.Pdt9 & GA.Bmpc5 & SC.Egpc6 & GA.Bp3 & SC.Egpc8 & GA.Bpc12 \\
\hline \multicolumn{11}{|c|}{ Azoxystrobin } \\
\hline $\mathrm{EC}_{50}$ & 0.06 & 0.43 & 0.26 & 0.08 & 0.52 & 0.71 & 1.54 & 1.13 & 2.02 & 4.05 \\
\hline MIC & 0.5 & 2.0 & 0.5 & 1.0 & 1.0 & 4.0 & 4.0 & 4.0 & 4.0 & 8.0 \\
\hline DI & $0.0 \mathrm{a}$ & $7.0 \mathrm{a}$ & $0.0 \mathrm{a}$ & $0.0 \mathrm{a}$ & $17.7 \mathrm{~b}$ & $20.7 \mathrm{~b}$ & $33.7 \mathrm{c}$ & $34.0 \mathrm{c}$ & $55.3 \mathrm{~d}$ & $100 \mathrm{e}$ \\
\hline DS & 0.0 & 0.0 & 0.0 & 0.0 & 11.3 & 23.7 & 46.2 & 33.1 & 55.8 & 74.0 \\
\hline Phenotype & $\mathrm{S}$ & $\mathrm{S}$ & $\mathrm{S}$ & $\mathrm{S}$ & $\mathrm{S}$ & RS & RS & RS & RS & RS \\
\hline \multicolumn{11}{|c|}{ Pyraclostrobin + boscalid } \\
\hline $\mathrm{EC}_{50}$ & 0.03 & 0.01 & 0.07 & 0.03 & 0.06 & 0.10 & 0.16 & 0.20 & 0.6 & 0.20 \\
\hline MIC & 0.1 & 0.1 & 0.1 & 0.1 & 0.1 & 1.0 & 1.0 & 1.0 & 1.0 & 1.0 \\
\hline DI & $0.0 \mathrm{a}$ & $0.0 \mathrm{a}$ & $5.0 \mathrm{a}$ & $0.0 \mathrm{a}$ & $9.0 \mathrm{a}$ & $8.8 \mathrm{~b}$ & $12.7 \mathrm{~b}$ & $39.1 \mathrm{c}$ & $69.7 \mathrm{~d}$ & $46.6 \mathrm{c}$ \\
\hline DS & 0 & 0 & 8.0 & 0 & 7.0 & 15.3 & 23.1 & 25.7 & 81.2 & 33.9 \\
\hline Phenotype & $\mathrm{S}$ & $\mathrm{S}$ & $\mathrm{S}$ & $\mathrm{S}$ & $\mathrm{S}$ & $\mathrm{S}$ & $\mathrm{S}$ & RS & RS & RS \\
\hline \multicolumn{11}{|l|}{ Boscalid } \\
\hline $\mathrm{EC}_{50}$ & 14.23 & 0.51 & 4.82 & 8.12 & 1.11 & 0.31 & 2.09 & 3.14 & 3.12 & 2.25 \\
\hline MIC & 50 & 5.0 & 10.0 & 20.0 & 5.0 & 5.0 & 10.0 & 20.0 & 10.0 & 8.0 \\
\hline DI & $87.1 \mathrm{e}$ & $0.0 \mathrm{a}$ & $59.7 \mathrm{~d}$ & $97.1 \mathrm{e}$ & $0.0 \mathrm{a}$ & $0.0 \mathrm{a}$ & $32.7 \mathrm{~b}$ & $46.5 \mathrm{~d}$ & $44.6 \mathrm{~d}$ & $26.6 \mathrm{~b}$ \\
\hline DS & 63.1 & 0 & 39.9 & 73.1 & 0 & 0 & 19.7 & 32.5 & 61.8 & 22.7 \\
\hline Phenotype & RS & $\mathrm{S}$ & RS & RS & $\mathrm{S}$ & $\mathrm{S}$ & RS & RS & RS & RS \\
\hline
\end{tabular}

${ }^{y}$ Values within the same row followed by the same letters are not significantly different based on the analysis of variance and least significant difference test at $P=0.05$. Disease incidence (DI) was expressed as the percent of wounds infected compared with the total number (18) of wounds inoculated. Disease severity (DS) was determined using the formula :DS\% = mean diameter in control - mean diameter in treatment/mean diameter in the control $\times 100$ ).

${ }^{\mathrm{z}}$ Azoxystrobin was applied as formulated Abound $2.08 \mathrm{~F}$ at $1.7 \mathrm{ml} /$ liter, whereas pyraclostrobin + boscalid and boscalid were applied as formulated products Pristine and Endura to previously disinfected peach fruit at 1.08 and $1.34 \mathrm{~g} /$ liter, respectively. $\mathrm{EC}_{50}=$ effective concentration of fungicide inhibiting mycelial growth by $50 \%$; MIC $=$ the minimum concentration inhibiting mycelial growth by $100 \%$; DI and DS values are the mean of six replicate-fruit across two experimental runs (three replicate fruit $\times$ two runs); and phenotypes $=$ sensitive $(\mathrm{S})$ and reduced-sensitive $(\mathrm{RS})$. 
QoI and SdhI mixture Pristine rather than a QoI or SdhI stand-alone product. At two locations in South Carolina, Pristine failed to control brown rot in two consecutive years. $\mathrm{EC}_{50}$ values of isolates from one of these locations (orchard DM) ranged between 3.8 and $20.1 \mu \mathrm{g} / \mathrm{ml}$ and 0.01 and $0.17 \mu \mathrm{g} / \mathrm{ml}$ for boscalid and pyraclostrobin, respectively. The grower had sprayed RI fungicides frequently since 2003 and used them exclusively for preharvest disease control in 2007 and 2008. Thus, it is likely that a breakdown in boscalid efficacy was responsible for the control failure.

The reliance on reduced-risk, single-site inhibitors for preharvest brown rot control has led to a situation where growers are facing unprecedented challenges. In the Southeast, growers are now facing resistance to benzimidazoles (36) and DMIs $(25,35)$ and, as demonstrated in this study, reduced sensitivity to RI fungicides. However, resistance to either chemical class is not widespread in every southeastern geographic location, justifying the need for the development of rapid, location-specific resistance profiling methods $(2,3)$.

\section{ACKNOWLEDGMENTS}

Technical contribution no. 5735 of the Clemson University Experiment Station. This material is based upon work supported by NIFA/United States Department of Agriculture, under project number SC-1000642. We thank A. Rollins, G. Henderson, W. Chai, and P. K. Bryson, Clemson University, South Carolina and F. Funderburk, University of Georgia, Georgia for their technical assistance.

\section{LITERATURE CITED}

1. Abbot, W. S. 1925. A method of computing the effectiveness of an insecticide. J. Econ. Entomol. 18:265-267.

2. Amiri, A., Brannen, P. M., and Schnabel, G. 2009. Validation of the Lipbalm Tube Assay for Evaluation of Fungicide Sensitivity in Field Isolates of Monilinia fructicola. Plant Health Progress doi:10.1094/PHP-20091118-01-RS

3. Amiri, A., Scherm, H., Brannen, P. M., and Schnabel, G. 2008. Laboratory evaluation of three rapid, agar-based assays to assess fungicide sensitivity in Monilinia fructicola. Plant Dis. 92:415-420.

4. Ammermann, E., Lorenz, G., Schelberger, K., Mueller, B., Kirstgen, R., and Sauter, H. 2000. BAS $500 \mathrm{~F}$ - the new broad-spectrum strobilurin fungicide. Pages 541-548 in: Proc. BCPC Conf. Pests Dis. BCPC, Farnham, Surrey, UK.

5. Avenot, H. F., Sellam, A., Karaoglanidis, G., and Michailides, T. J. 2008. Characterization of mutations in the iron-sulphur subunit of succinate dehydrogenase correlating with boscalid resistance in Alternaria alternata from California pistachio. Phytopathology 98:736-742.

6. Bartlett, D. W., Clough, J. M., Godwin, J. R., Hall, A. A., Hamer, M., and Parr-Dobrzanski, B. 2002. The strobilurin fungicides. Pest Manage. Sci. 58:649-662.

7. Becker, W. F., von Jagow, G., Anke, T., and Steglich, W. 1981. Oudemansin, strobilurin A, strobilurin B and myxothiazole: new inhibitors of the $b c 1$ segment of the respiratory chain with an E-b-methoxyacrylate system as common structural element. FEBS Lett. 132:329333.

8. Cox, K. D., Bryson, P. K., and Schnabel, G. 2007. Instability of propiconazole resistance and fitness in Monilinia fructicola. Phytopathology 97:448-453.

9. Fernández-Ortuño, D., Torés, J. A., de Vicente, A., and Pérez-García, A. 2008. Field resistance to QoI fungicides in Podosphaera fusca is not supported by typical mutations in the mitochondrial cytochrome $b$ gene. Pest Manage. Sci. 64:694-702.

10. Gisi, U. 1996. Synergistic interaction of fungicides in mixtures. Phytopathology 86:12731279.

11. Ishii, H., Fraaije, B. A., Sugiyama. T., Noguchi. K., Nishimura. K., Takeda, T., Amano, T., and Hollomon D. W. 2001. Occurrence and molecular characterization of strobilurin resistance in cucumber powdery mildew and downy mildew. Phytopathology 91:1166-1171.

12. Jiang, J., Ding, L., Michailides, T. J., Li, H., and Ma, Z. 2008. Molecular characterization of field azoxystrobin-resistant isolates of $\mathrm{Bo}$ trytis cinerea. Pestic. Biochem. Physiol. 92:7276.

13. Kim, Y. S., Dixon, P., Vincelli, P., and Farman, M.L. 2003. Field resistance to strobilurin (QoI) fungicides in Pyricularia grisea caused by mutations in the mitochondrial cytochrome $b$ gene. Phytopathology 93:891-900

14. Köller, W. K., Parker, D. M., Turechek, W. W., Avila-Adame, C., and Cronshaw, K. 2004. A two-phase resistance response of Venturia inaequalis populations to the QoI fungicides kresoxim-methyl and trifloxystrobin. Plant Dis. 88:537-544.

15. Kuhn, P. J. 1984. Mode of action of carboxamides. Symp. Ser. Br. Mycol. Soc. 9:155-183.

16. Lu, Y. L., Sutton, T. B., and Ypema, H. 2003. Sensitivity of Alternaria mali from North Carolina apple orchards to pyraclostrobin and boscalid. (Abstr.) Phytopathology 93:S54

17. Miazzi, M., and McGrath, M. T. 2008. Sensitivity to Podosphaera xanthii to registered fungicides and experimental in GA and NY, USA in 2007. J. Plant. Pathol. 90:S-90.

18. Mondal, S. N., Bhatia, A., Shilts, T., and Timmer, L. W. 2005. Baseline sensitivities of fungal pathogens of fruit and foliage of citrus to azoxystrobin, pyraclostrobin, and fenbuconazole. Plant Dis. 89:1186-1194.

19. Myresiotis, C. K., Bardas, G. A., and Karaoglanidis, G. S. 2008. Baseline sensitivity of Botrytis cinerea to pyraclostrobin and boscalid and control of anilinopyrimidine- and benzimidazoleresistant strains by these fungicides. Plant Dis. 92:1427-1431.

20. Olaya, G., Zheng, D., and Köller, W. 1998. Differential responses of germinating Venturia inaequalis conidia to kresoxim-methyl. Pestic. Sci. 54:230-236.

21. Pasche, J. S., Piche, L. M., and Gudmestad, N. C. 2005. Effect of the F129L mutation in $\mathrm{Al}$ ternaria solani on fungicides affecting mitochondrial respiration. Plant Dis. 89:269-278.

22. Rebollar-Alviter, A., Madden, L. V., Jeffers, S. N., and Ellis, M. A. 2007. Baseline and differential sensitivity to two QoI fungicides among isolates of Phytophthora cactorum that cause leather rot and crown rot on strawberry. Plant Dis. 91:1625-1637.

23. Ritchie, D., and Pollard, W. 2001. Evaluation of different rates of BAS 516 for control of brown rot on peach fruit. Fungic. Nematicide Tests 56:STF6.
24. Sauter, H., Ammermann, E., Benoit, R., Brand, S., Gold, R. E., Grammenos, W., Köhle, H., Lorenz, G., Müller, B., Röhl, F., Schirmer, U., Speakman, J., Wenderoth, B., and Wingert, $\mathrm{H}$. 1995. Mitochondrial respiration as a target for antifungals: Lessons from research on strobilurins. Pages 173-192 in: Antifungal Agents-Discovery and Mode of Action. G. K Dixon, L. G. Copping, and D. W. Hollomon, eds. BIOS Scientific Publishers, Oxford

25. Schnabel, G., Bryson, P. K., Bridges, W. C., and Brannen, P. M. 2004. Reduced sensitivity in Monilinia fructicola to propiconazole in Georgia and implications for disease management. Plant Dis. 88:1000-1004.

26. Schnabel, G., Dai, Q., and Paradkar, M. R. 2003. Cloning and expression analysis of the ATP binding cassette transporter MFABCl gene and the alternative oxidase gene MfAOXI from Monilinia fructicola. Pest Manage. Sci. 59:1143-1151

27. Sierotzki, H., Parisi, S., Steinfeld, U., Tenzer I., Poirey, S., and Gisi, U. 2000. Mode of resistance to respiration inhibitors at the cytochrome bclcomplex of Mycosphaerella fijiensis. Pest Manage. Sci. 56:833-841.

28. Sierotzki, H., Wullschleger, J., and Gisi, U. 2000. Point-mutation in cytochrome $b$ gene conferring resistance to strobilurin fungicides in Erysiphe graminis f. sp. tritici field isolates. Pestic. Biochem. Physiol. 68:107-112.

29. Spiegel, J., and Stammler, G. 2006. Baseline sensitivity of Monilinia laxa and M. fructigena to pyraclostrobin and boscalid. J. Plant Dis. Prot. 113:199-206.

30. Stammler, G., Brix, H. D., Nave, B., Gold, R. and Schoefl, U. 2007. Studies on the biological performance of boscalid and its mode of action. (Abstr.) Int. Reinhardsbrunn Symp. 15th. Modern Fungicides and Antifungal Compounds. Friedrichroda, Germany.

31. Steinfeld, U., Sierotzki, H., Parisi, S., and Gisi, U. 2002. Comparison of resistance mechanisms to strobilurin fungicides in Venturia in aequalis. Pages 167-176 in: Modern Fungicides and Antifungal Compounds II, 13th Int. Reinhardsbrunn Symp. H. Lyr, P. E. Russell, H.-W. Dehne, U. Gisi, and K.-H. Kuck, eds. AgroConcept, Bonn, Verlag Th. Mann Gelsenkirchen, Germany.

32. Ulrich, J. T., and Mathre, D. E., 1972. Mode of action of oxathiin systemic fungicides V. Effect on electron transport system of Ustilago maydis and Saccharomyces cerevisiae. J. Bacteriol. 110:628-632.

33. Vincelli, P., and Dixon, E. 2002. Resistance to QoI (strobilurin-like) fungicides in isolates of Pyricularia grisea from perennial ryegrass. Plant Dis. 86:235-240.

34. Wong, F. P., Midland, S. L., and de la Cerda, K. A. 2007. Occurrence and distribution of QoI-resistant isolates of Colletotrichum cereale from annual bluegrass in California. Plant Dis. 91:1536-1546.

35. Zehr, E. I., Luszcz, L. A., Olien, W. C., Newall, W. C., and Toler, J. E. 1999. Reduced sensitivity in Monilinia fructicola to propiconazole following prolonged exposure in peach orchards. Plant Dis. 83:913-916.

36. Zehr, E. I., Toler, J. E, and Luszcz, L. A. 1991. Spread and persistence of benomyl-resistant Monilinia fructicola in South Carolina peach orchards. Plant Dis. 75:590-593.

37. Zhang, C. Q., Yuan, S. K., Sun, H. Y., Qi, Z. Q., Zhou, M. G., and Zhu, G. N. 2007. Sensitivity of Botrytis cinerea from vegetable greenhouses to boscalid. Plant Pathol. 56:646653. 